\title{
Study on assessing the impact of climate change (temperature and rainfall) on rice yield in the Long Xuyen Quadrangle region (LXQR) - Vietnam
}

\author{
Can Thu Van ${ }^{*}$, Phan Thi Thuy Duong ${ }^{1}$, Dinh Thi Nga ${ }^{1}$, Luu Van Ninh ${ }^{2}$ \\ ${ }^{1}$ Ho Chi Minh City University of Natural Resources and Environment, 236B Le Van Sy, \\ ward 1, Ta Binh, Ho Chi Minh City; ctvan@hcmunre.edu.vn; pttduong@hcmunre.edu.vn; \\ dtnga@hcmunre.edu.vn; \\ ${ }^{2}$ Hydro-Meteorology Center of An Giang Province, 64 Ton Duc Thang, My Binh ward, \\ Long Xuyen City, An Giang; luuninhtv@gmail.com; \\ *Correspondence: ctvan@hcmunre.edu.vn; Tel.: +84-983738347 \\ Received: 25 December 2020; Accepted: 16 April 2021; Published: 25 April 2021
}

\begin{abstract}
The impacts of climate change such as sea level rise, floods, droughts, saltwater intrusion, extreme weather ... are more and more evident. It causes significant damage to the socio-economy of Vietnam, especially the rice farming industry. In Vietnam, over the past 50 years, the average temperature has risen by about 2-3 degrees Celsius and the sea level has risen by about $20 \mathrm{~cm}$. According to the simulation scenarios, it is estimated that by the end of the twenty-first century, compared to the average in the period 1980-2005, the average temperature in Vietnam could increase by 2.3 degrees Celsius, the annual rainfall would increase by about $5 \%$. and the sea level could rise by $75 \mathrm{~cm}$. There are many influencing factors affecting rice yield such as: meteorological factors, hydrology, saline intrusion, farming, pests,... This study, only the change in yield is assessed rice due to the impact of changes in temperature and precipitation in the context of climate change in the LXQR). By using the CROPWAT model to calculate rice yields with temperature changes and rainfall over periods according to climate change scenarios, the results show that under the RCP4.5 scenario when heat If the degree and rainfall increase, the rice yield decreases by $25.4 \%$ on average; RCP 8.5 rice yield decreased by $25.3 \%$ on average.
\end{abstract}

Keywords: LXQR; Climate change; Cropwat; Rice yield; Assessment of the damage.

\section{Introduction}

Climate change has been one of the biggest challenges facing people, the negative impacts of climate change on human life are becoming more and more obvious [1-2]. The direct effects of climate change on water resources are abnormal rainfall changes, rising temperatures and extreme weather events such as long-term droughts and mid-to-saturated floods. Climate change will affect water resources and reduce water resources in many places, leading to water scarcity [3]. Water scarcity is a major problem for many developing countries, including Vietnam, especially in relation to agricultural irrigation in the Mekong River Delta (MRD) and the LXQR. where there is a serious shortage of fresh water in the dry season for many different reasons. For rice, the variation of yield and yield has a great participation of hydro-meteorological factors [4]. To estimate and evaluate the impact of hydro-meteorological factors on crop yields in general and rice in particular, the Food and Agriculture Organization (FAO) developed a CropWat model in 1990, based on temperature conditions, precipitation, sunny hours, humidity, wind speed [5-6].

LXQR is a quadrilateral-shaped land in the MRD, located in three provinces of Kien Giang, An Giang and Can Tho. The four sides of the LXQR are the Vietnam-Cambodia border, the Gulf of Thailand, the Cai San canal and the Bassac River (Hau River). The four 
corner vertices of this quadrilateral correspond to four cities: Chau Doc, Long Xuyen, Rach Gia and Ha Tien (Figure 1). The LXQR is one of the major food production and processing centers in the MRD. Formerly An Giang, and now Kien Giang is the locality with the largest rice production in the region. This is the area that has positively contributed to the overall achievement of the MRD region.

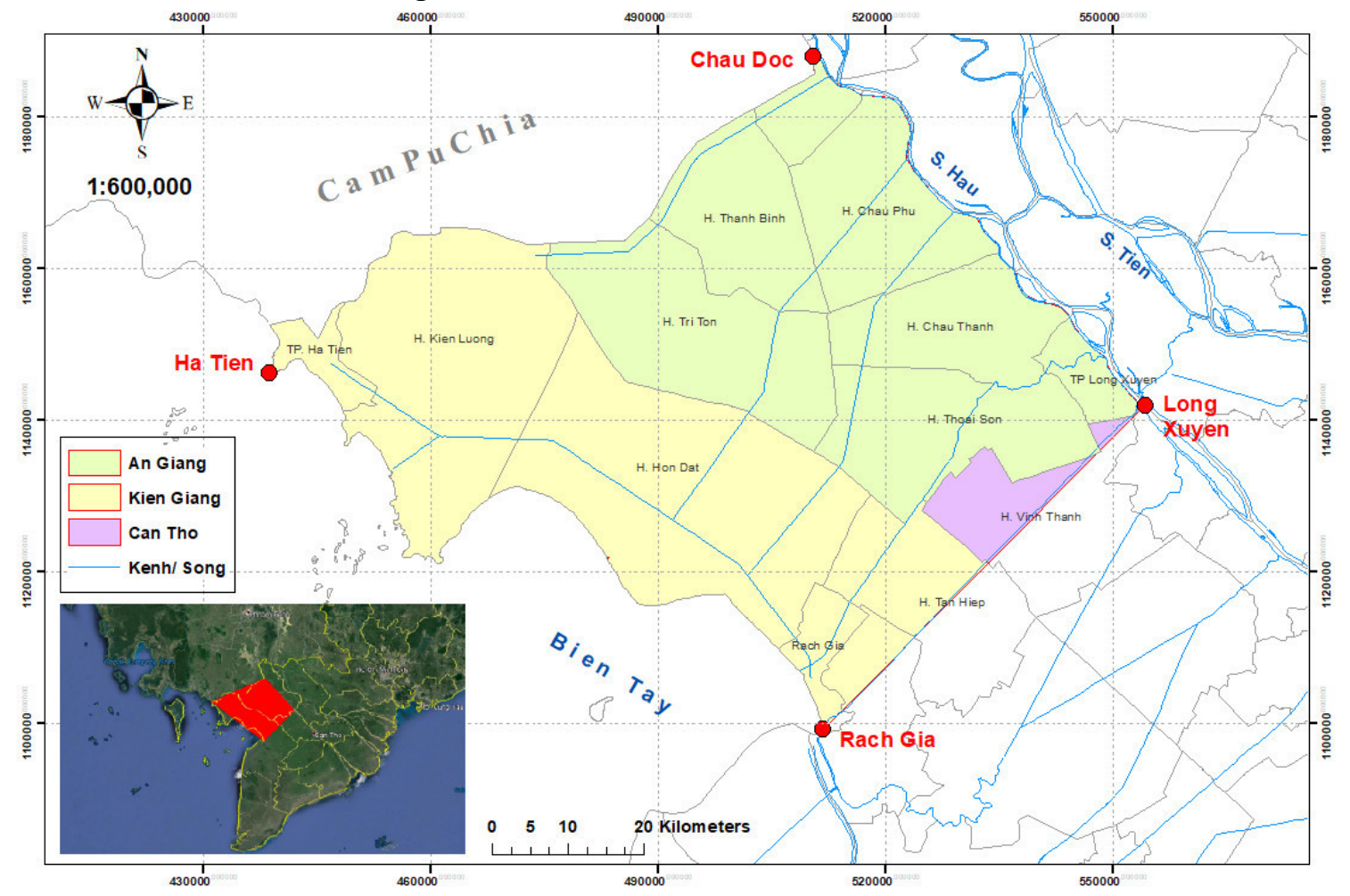

Figure 1. Study area of LXQR.

In the next period, it is forecasted that the LXQR region will face many challenges, in which the issue of climate change and the possibility of droughts, increased saltwater intrusion due to sea level rise. Rice is playing a very important role in the agricultural sector. industry of the region. In Vietnam, over the past 50 years, the average temperature has risen by about 2-3 degrees Celsius and the sea level has risen by about $20 \mathrm{~cm}$ [7]. According to the simulation scenarios, it is estimated that by the end of the twenty-first century, compared to the average in the period 1980-2005, the average temperature in Vietnam could increase by 2.3 degrees Celsius, the annual rainfall would increase by about $5 \%$. and the sea level could rise by $75 \mathrm{~cm}$. The change of hydro-meteorological factors in the region can affect crop yield in general and rice yield in particular [8]. The study is conducted to evaluate the impact of hydro-meteorological factors on rice productivity in the study area through future climate change scenarios and thereby calculate the amount of damage caused by the impacts of Climate change through temperature and precipitation factors. The results of this study help to provide useful information for managers in making policies and strategies for the development of agricultural production in the future in the context of global climate change.

\section{Materials and Methods}

\subsection{Methodology}

This paper uses CROPWAT 8.0 software, which is the most advanced irrigation regimen software released in 1992, developed and recommended by the FAO for worldwide use. Plant water requirements and irrigation planning based on the data provided by the user [9] (Figure 2). 


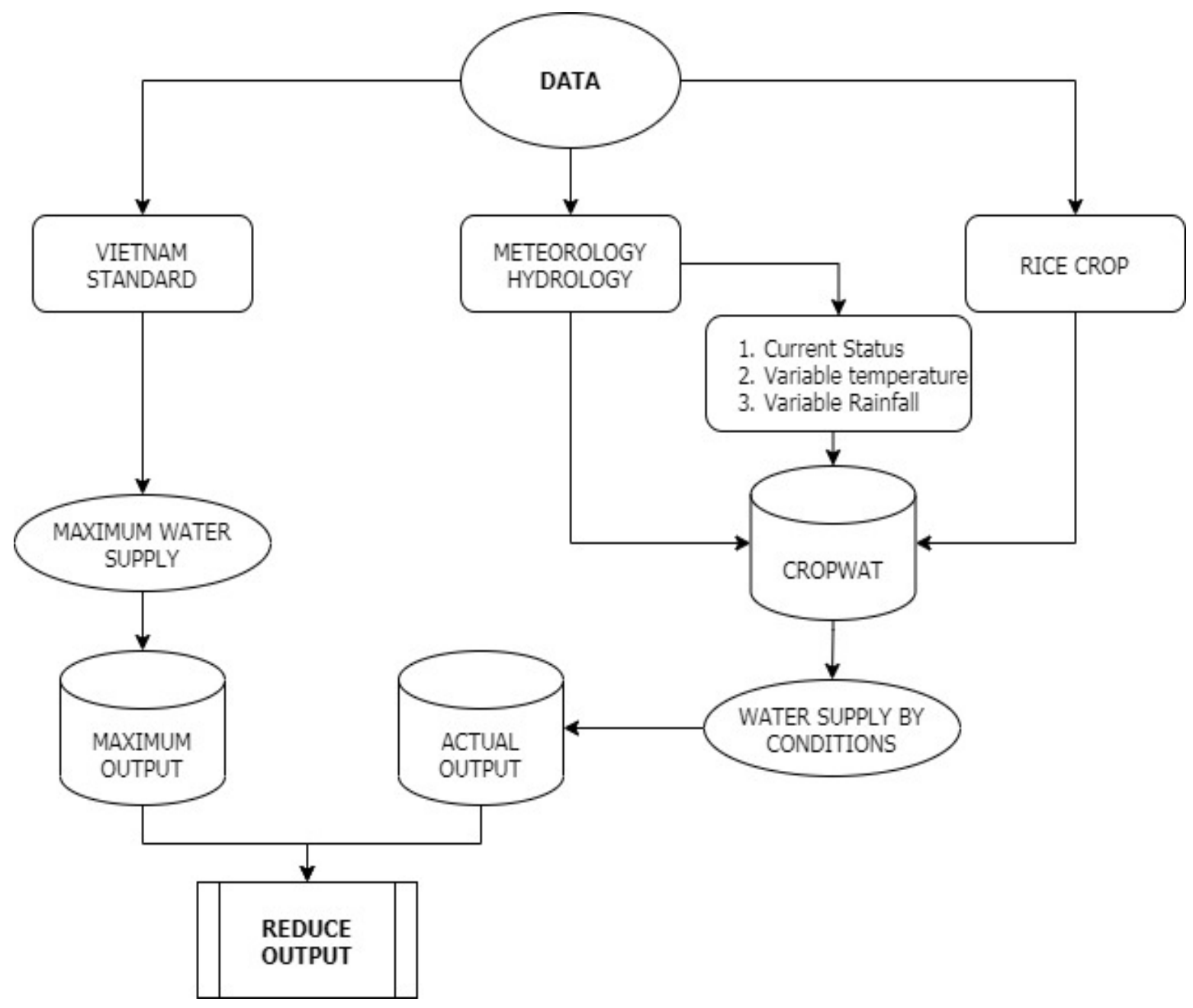

Figure 2. Diagram of implementation steps.

According to [9], the response of crop yield to irrigation water was quantified by a crop yield reduction factor $(\mathrm{KY})$, related to a relative yield decrease $(1-\mathrm{Ya} / \mathrm{Ym})$ for a Relative water demand deficit (1-ETa/ETc). Therefore, the Ky values for most crops are based on the assumption that the relationship between relative yield $(\mathrm{Ya} / \mathrm{Ym})$ and relative water demand $(\mathrm{ETa} / \mathrm{ETc})$ is linear and has a value for water deficit amounts to about $50 \%$ or $1-\mathrm{ETa} / \mathrm{ETc}=$ 0.5 .

According to [3], the yield reduction coefficient is of experimental origin $\left(\mathrm{K}_{\mathrm{y}}\right)$ for the individual growth stages (i.e., establishment, vegetation, flowering, yield formation, or period). segment nine) as well as during total growth.

$$
\left(1-\frac{\mathrm{Y}_{\mathrm{a}}}{\mathrm{Y}_{\mathrm{m}}}\right)=\mathrm{K}_{\mathrm{y}}\left(1-\frac{\mathrm{ET}_{\mathrm{a}}}{\mathrm{ET}_{\mathrm{c}}}\right)
$$

where $\mathrm{Ya}$ is the real yield (corresponding to ETa) $(\mathrm{kg} / \mathrm{ha})$; $\mathrm{Ym}$ is the maximum theoretical yield (corresponding to ETc) ( $\mathrm{kg} / \mathrm{ha})$; Eta is the actual water demand ( $\mathrm{mm} /$ day) for each crop; Etc-potential water demand for each crop; $\mathrm{K}_{\mathrm{Y}}$ is the yield response coefficient to water stress. yield:

To get the actual yield, multiply the relative seasonal yield by the maximum theoretical

$$
\mathrm{Y}_{\mathrm{a}}=\mathrm{Y}_{\mathrm{m}}\left(1-\mathrm{K}_{\mathrm{y}}\left(1-\frac{\mathrm{ET}_{\mathrm{a}}}{\mathrm{ET}_{\mathrm{c}}}\right)\right)
$$

Then, the yield price of crops and fisheries is calculated by the formula [9]: 


$$
\text { Market Value }=\text { Ya } * \text { Area } * \text { Price }
$$

where Market Value is the quantity of output of crops/aquatic products (\$); Ya is an actual yield ( $\mathrm{kg} / \mathrm{ha})$; Area is the cultivated area (ha); Price is the market price of crop/seafood per unit area $(\$ / \mathrm{kg})[10-12]$.

\subsection{Data collection}

\subsubsection{Hydro-Meteorology Data}

Meteorological and hydrological data collected up to 2018 provided by the Hydrometeorology Center of An Giang province (Chau Doc station) and the hydrometeorological center of Kien Giang province (Rach Gia station) have been revised, reliable enough, is the basis in calculating the price of agricultural productivity and climate change scenarios in terms of rainfall, temperature, average number of hours of sunshine, humidity, wind speed and other characteristics for this study [13-16].

\subsubsection{Socio-economic data}

Data on natural conditions, socioeconomic, and agricultural production in the MRD in 2018 are released by the General Statistics Office, the Ministry of Planning and Investment [17-19].

\subsubsection{Documents related to rice plants}

Rice seasons in the region according to the development stages and Kc coefficients of each growing period of rice are shown in Table 1 and Table 2 below.

Table 1. Rice seasons in the study area [10].

\begin{tabular}{llccccccc}
\hline No. & Rice crops & $\begin{array}{c}\text { Prepare } \\
\text { the land } \\
\text { (I) }\end{array}$ & $\begin{array}{c}\text { Initial } \\
\text { stage } \\
\text { (II) }\end{array}$ & $\begin{array}{c}\text { Development } \\
\text { stage } \\
\text { (III) }\end{array}$ & $\begin{array}{c}\text { Harvesting } \\
\text { stage } \\
\text { (IV) }\end{array}$ & $\begin{array}{c}\text { Planting } \\
\text { time }\end{array}$ & $\begin{array}{c}\text { Harvest } \\
\text { time }\end{array}$ & $\begin{array}{c}\text { Number } \\
\text { of days }\end{array}$ \\
\hline $\begin{array}{l}\text { Winter } \\
\text { spring Crop } \\
\text { Summer- }\end{array}$ & 10 & 10 & 60 & 25 & $15 / 12$ & $30 / 3$ & 105 \\
$2 \quad$ & 10 & 10 & 65 & 31 & $15 / 4$ & $06 / 8$ & 111 \\
autumn & & 10 & 60 & 20 & $20 / 8$ & $30 / 11$ & 100 \\
\hline $\begin{array}{l}\text { Crop } \\
\text { October }\end{array}$ & 10 & 10 & & & & & \\
\hline
\end{tabular}

Table 2. Kc coefficients of rice plants in the study area [11-12].

\begin{tabular}{lcccc}
\hline \multicolumn{1}{c}{ Rice crops } & $\begin{array}{c}\text { Prepare the } \\
\text { land (I) }\end{array}$ & $\begin{array}{c}\text { Initial stage } \\
\text { (II) }\end{array}$ & $\begin{array}{c}\text { Development } \\
\text { stage } \\
\text { (III) }\end{array}$ & $\begin{array}{c}\text { Harvesting } \\
\text { stage } \\
\text { (IV) }\end{array}$ \\
\hline Winter spring Crop & 0,30 & 0,54 & 1,05 & 0,81 \\
Summer-autumn Crop & 1,03 & 1,19 & 1,74 & 1,12 \\
October Crop & 1,04 & 1,17 & 1,68 & 1,14 \\
\hline
\end{tabular}




\subsubsection{Climate change scenarios}

According to the climate change scenarios of the Ministry of Natural Resources and Environment [5], the beginning of the century (2016-2035) between the century (20452065 ) and the end of the century (2080-2099) with 2 scenarios of the emission concentration medium low (RCP4.5) and high (RCP8.5) [20-21].

This study is limited to the study period from the beginning of 2016-2035 and according to that result, the temperature of the period is expected to change (increase) compared to the standard period (1992-2018) at the An Giang meteorological station. And Kien Giang in two scenarios as shown in Table 3 below.

Table 3. Scenario of change in temperature and average rainfall in the period 2016-2035 [6].

\begin{tabular}{lcccc}
\hline & \multicolumn{2}{c}{ RCP4.5 } & \multicolumn{2}{c}{ RCP8.5 } \\
\cline { 2 - 5 } & An Giang & Kien Giang & An Giang & Kien Giang \\
\hline Temperature $\left({ }^{\circ} \mathrm{C}\right)$ & +0.7 & +0.7 & +0.9 & +0.8 \\
Amount of rain $(\%)$ & +4.7 & +4.9 & +8.2 & +6.5 \\
\hline
\end{tabular}

\section{Results and discusion}

\subsection{Effect of temperature on rice yield}

The average temperature increase under the RCP 4.5 and RCP 8.5 scenarios is $0.7^{\circ} \mathrm{C}$ and $0.9^{\circ} \mathrm{C}$ respectively, generally making the rice yields of the rice growing districts in the LXQR decrease.

Specifically:

In winter-spring crop (WSC), ETc evaporation according to RCP 4.5 scenario is 689.8 $\mathrm{mm}$ /day and according to RCP 8.5 is $693.7 \mathrm{~mm} /$ day (data extracted from the results simulating the Cropwat model), while the actual water demand is $770 \mathrm{~mm} /$ day (TCVN), the water demand is not enough according to reality, thus reducing rice yield. Compared to the maximum yield of the WSC crop (8.00 tons/ha), when the temperature increases by $0.7^{\circ} \mathrm{C}$ under the RCP 4.5 scenario, the productivity of the WSC 4.5 crop decreases by $10.5 \%$ (equivalent to 0.84 tons/ha). When the temperature increased by $0.9^{\circ} \mathrm{C}$ under the RCP 8.5 scenario, the rice yield decreased $10.0 \%$ (equivalent to 0.80 tons/ha. In addition, the WSC coincides with the dry season, the evaporation of water evaporation increases, the water demand for plants is less, rainfall and other factors do not change, so rice yield decreases (Figure 3).

In the summer-autumn crop (SAC), rice yields decreased by $43.3 \%$ (equivalent to 2.59 tons/ha) and $43.7 \%$ (equivalent to 2.62 tons/ha), respectively. The evaporation of ETc of SAC crop under RCP 4.5 scenario is $956.7 \mathrm{~mm}$ /day and under RCP 8.5 scenario is 962.3 $\mathrm{mm} /$ day (data extracted from the modeling results of Cropwat), meanwhile Actual water demand is $580 \mathrm{~mm} /$ day $(\mathrm{TCVN})$.

In the October crop (OC), rice yield decreased by $24.5 \%$ and $25.1 \%$, respectively (decreasing by 1.71 tons/ha and 1.76 tons/ha). The evaporation of ETc of the OC under the RCP 4.5 scenario is $652 \mathrm{~mm} /$ day and under the RCP 8.5 scenario is $657 \mathrm{~mm} /$ day (data extracted from the modeling results of the Cropwat model), the actual water demand is 500 . $\mathrm{mm}$ /day (TCVN). The OC also coincides with the rainy season, with a lot of rainfall, the amount of water needed for plants is greater than the actual demand, thus affecting yield. (Figure 3).

In general, when temperature increases, rainfall, humidity, sunny hours, and wind speed do not change, the amount of water evaporation increases, but the amount of water needed for plants is limited, affecting yield rice in crops. 


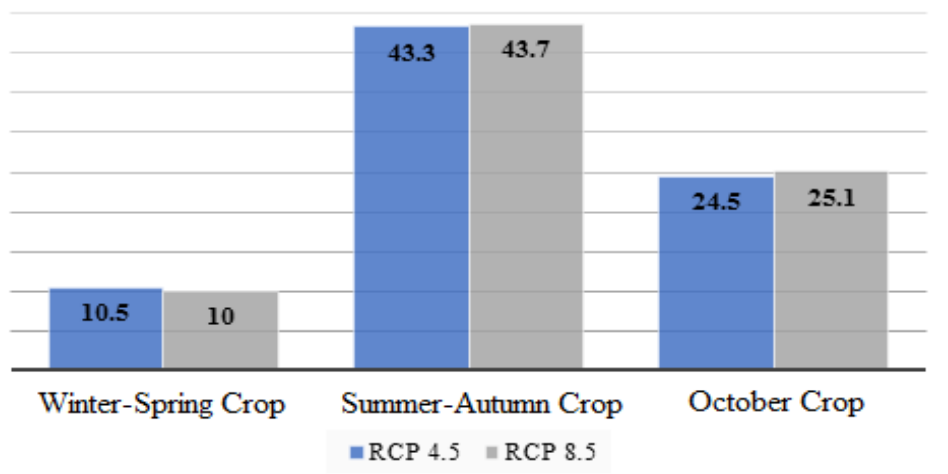

Figure 3. Rate of decrease in rice yield due to the effect of temperature under climate change scenarios $(\%)$.

\subsection{Effects of changes in rainfall caused by climate change on rice yield}

The average rainfall under the RCP 4.5 scenario increased by $4.7 \%$ and the RCP 8.5 by $8.2 \%$, in general, both resulted in a decrease in rice yields of the crops.

Specifically:

In Winter-Spring crop, rice yield decreased by $12.2 \%$ and $12.5 \%$, respectively (down 0.98 tons/ha and 1.00 tons/ha) compared to the maximum yield of the crop when it rains. increased by $4.7 \%$ and $8.2 \%$, respectively. According to simulation results from CROPWAT model, the evaporation of ETc in the DXP 4.5 scenario is $676.9 \mathrm{~mm} /$ day and according to the RCP 8.5 scenario is $674.8 \mathrm{~mm} /$ day. The time of the winter season coincides with the dry season, temperature and other meteorological factors do not change, but the future rainfall will increase to exceed the potential water demand of the rice crop, thus affecting the rice yield but not much (Figure 4).

The productivity of Summer-Autumn rice crop also decreased, according to simulation results from CROPWAT model, ETc evaporation of HT crop under RCP 4.5 scenario was $923.8 \mathrm{~mm}$ /day and under RCP 8.5 scenario $915.0 \mathrm{~mm} /$ day, while the actual water demand is only $580 \mathrm{~mm} /$ day $(\mathrm{TCVN})$. According to the scenarios with increased rainfall, the yield of HT crop rice decreases sharply. Rice yield decreased by $40.9 \%$ and $40.3 \%$, respectively (decreasing equivalent to 2.46 tons/ha and 2.42 tons/ha). In general, when temperature and other factors do not change, rainfall greatly affects the yield of SAC (Figure 4).

In the October crop, rice yield decreased by $20.7 \%$ and $19.9 \%$ respectively (decreasing equivalent to 1.45 tons/ha and 1.39 tons/ha). According to simulation results from CROPWAT model, the evaporation of ETc of Seasonal crop under RCP 4.5 scenario is 622.8 $\mathrm{mm} /$ day and under RCP 8.5 scenario is $616.8 \mathrm{~mm} /$ day, meanwhile Actual water demand is $500 \mathrm{~mm} /$ day (TCVN) so rice yield is affected (Figure 4).

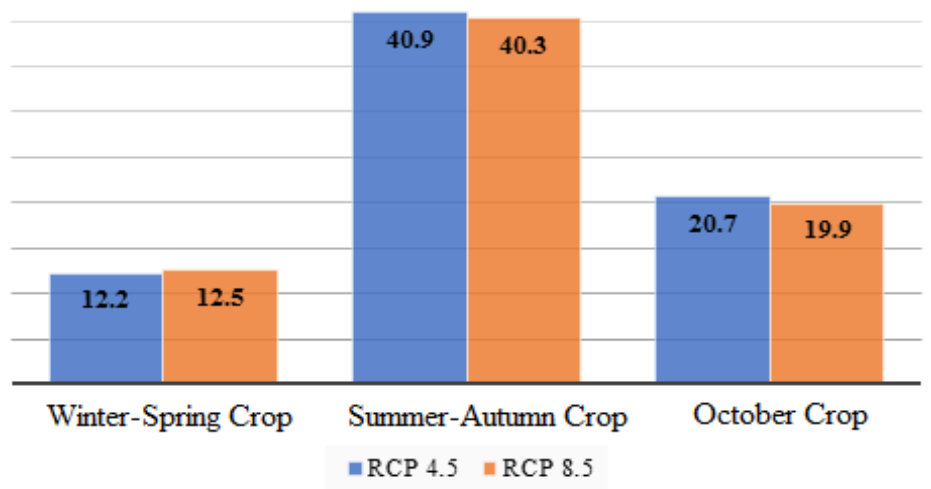

Figure 4. Rate of decrease in rice yield due to the effect of rainfall under climate change scenarios (\%). 
In summary, when the rainfall increases, the factors of temperature, humidity, sunshine hours, and wind speed do not change, the amount of evaporation will decrease compared to the baseline period, the water demand needed for plants is met. Excess compared to the potential water demand, thus affecting the rice yield in the crops.

\section{Conclusions}

When the temperature increases, the rainfall, humidity, sunny hours, and wind speed do not change, the amount of water evaporation increases, but the amount of water needed for plants is limited, thus reducing the rice yield. in cases.

When the rainfall increases, the factors of temperature, humidity, number of hours of sunshine, and wind speed do not change, the amount of evaporation will decrease compared to the baseline period, the water demand needed for tall trees is met. With the potential water demand, the rice yield in the crops is also reduced.

In addition to temperature and precipitation, other meteorological factors such as wind, humidity, hours of sunshine,... also affect rice yield and will be considered in later studies. In fact, climatic factors have a mutual relationship: the change of one factor leads to the change of another factor. Therefore, there should be more in-depth studies on the effects of these factors on rice yields in particular and crops in general.

Calculation results in the study have shown the impact of climate change, namely the increase in temperature and rainfall in the Mekong Delta on the rice yield here.

As mentioned from the beginning, the study just stopped at assessing the impact of two independent factors, temperature and precipitation, so the results have not been fully and accurately reflected. These factors will be calculated and included in the evaluation in the next studies.

Author contribution statement: Research ideas, build scientific bases and methods to calculate yield losses of rice crops due to changes in temperature and rainfall due to climate change: C.T.V.; Orientation for data collection and use to calculate water demand for rice plants; Write the manuscript and correct the article; Applying SWAT model to calculate water demand for rice and calculate rice yield according to scenarios: P.T.T.D.; Build a scientific basis to determine the maximum yield of rice and Analyze the calculation results: D.T.N.; Collect, edit, process survey data, survey on the hydro-meteorological situation, economy, society and rice in the TGDXX: L.V.N.; Analysis of local climate change conditions as an input to the calculation model: C.T.V.

Acknowledgments: The article is made and completed on the database from products under the subject of the Ministry of Natural Resources and Environment, "Establishing the scientific basis of economic evaluation of water resources vulnerability under the impact of climate change; trials for rice, seafood and fruit trees in LXQR" MS: TNMT.2018.02.12. The authors sincerely thank you.

Competing interest statement: The authors declare no conflict of interest.

\section{References}

1. Duong, V.N.; Thai, M.T.; Do, H.T. Assessment of water resource demand and reserves for agricultural production in LXQR, Kien Giang province, 2015-2016. J. Agric. Rural Dev. 2019, 1, 70-79.

2. McGuire, S. FAO, IFAD, and WFP. The state of food insecurity in the world 2015: meeting the 2015 international hunger targets: taking stock of uneven progress. Rome: FAO, ed: Oxford University Press, 2015.

3. McGuire, S. WHO, World Food Programme, and International Fund for Agricultural Development. The State of Food Insecurity in the World 2012. Economic growth is 
necessary but not sufficient to accelerate reduction of hunger and malnutrition. Rome, FAO. (Eds). Oxford University Press. 2013.

4. Nguyen, V.V.; Nguyen, V.L.; Ngo, T.G.; Nguyen, H.S. Impacts of climate changes on yield of Dong Xuan rice in Son La province and coping measures. Sci. Tech. Hydrometeorol. J. 2002, 504, 1-9.

5. Lee, S.K.; Dang, T.A. Predicting the water use-demand as a climate change adaptation strategy for rice planting crops in the Long Xuyen Quadrangle Delta. Paddy Water Environ. 2019, 17, 561-570.

6. Nguyen, T.T.; Van, P.D.T.; Nguyen, H.T. Flow dynamics in the Tu Giac Long Xuyen area under the impact of a dyke to prevent floods. J. Sci. Can Tho University 2013, 25A, 85-93.

7. Nguyen, T.M.H.; Tran, V.T.; Huynh, V.T.M.; Van, P.D.T. Evaluate the effects of hydro-meteorological factors and agricultural production on rice productivity in the mezzanine area in An Giang province. J. Sci. Can Tho University 2012, 23A, 165173.

8. Luu, V.N. Research on building hydro-meteorological database of An Giang province in the context of climate change. General report on scientific research projects at An Giang province, 2018.

9. MONRE. Climate change and sea level rise scenarios for Vietnam. Vietnam Map and Environmental Resources Publishing House, 2016.

10. Doorenbos, J.; Kassam, A. Yield response to water. Irrigation Drainage Paper 1979, 33, pp. 257.

11. Allen, R.G.; Pereira, L.S.; Raes, D.; Smith, M. Crop Evapotranspiration-Guidelines for computing crop water requirements-FAO Irrigation and drainage paper 56. Fao. Rome. 1998, 300, D05109.

12. Hydraulic structure-Irrigation and drainage system - Method of irrigation coefficient determination for rice crop, 2012.

13. Tuan, N.D.; Van, C.T. Impact Assessment of Climate Change on Surface Water Resources in An Giang Province. J. Sci. VNU Sci. Technolo. 2015, 31(3S), 261-268.

14. Tuan, N.D.; Van, C.T.; Truong, C.D.; Khanh, N.T.; Anh, V.T.V.; Hong, N.V. Design of Decision Support Systems for Management of Land and Water Resources in Mekong Delta Responding to Climate Change. Sci. Tech. Hydrometeorol. J. 2015, 659, 34-41.

15. Tuan, N.D.; Can, T.V.; Truong, C.D.; Huong, L.T.V. Building and Integrating Information for Building Decision Support System (DSS) in Land and Water Management in the Mekong Delta for Climate Change Response. Sci. Tech. Hydrometeorol. J. 2015, 660, 32-37.

16. Hai, T.X.; Nghi, V.V.; Hung, V.H.; Tuan, D.N.; Lam, D.T.; Van, C.T. Assessing and Forecasting Saline Intrusion in the Vietnamese Mekong Delta under the Impact of Upstream Flow and Sea Level Rise. J. Environ. Sci. Eng. B 2019, 8, 174-185. https://doi.org/10.17265/2162-5263/2019.05.005

17. Van, C.T.; Son, N.T. Study on hydrological and hydraulic simulation in the Mekong Delta to evaluate the impact of the ring dike system on the surface flow change in Dong Thap Muoi area. Sci. Earth Environ. 2016, 32(3S), 256-263.

18. Tuan, N.D.; Van, C.T.; Phuong, P.V.H.; Huong, L.T.V. Building the knowledge base serves establishing decision support system (DSS) for land and water resources management in The Mekong River Delta response to climate change. Procceding ICENR ILTER-EAP Ecological insights and environmental protection for sustainable development under climate changes in East-Asia and Pacific regions $10 / 2016$. 
19. Van, C.T.; Tri, D.Q.; Son, N.T.; Thao, T.T.T.; Hoa, D.T.H. Determining the vulnerability index in the context of high floods in An Giang province. IOP Conf. Ser. Earth Environ. Sci. 2019, 307, 012015, https://doi.org/10.1088/17551315/307/1/012015.

20. Vo, T.D.; Le, T.S.; Vo, D.M.L. Analysis of factors affecting yield of winter-spring paddy in agro-ecological zones along the west coast of Mekong Delta. J. Sci. Can Tho University 2019, 55(5D), 99-108.

21. Bao, T.; Nguyen, T.P.; Bui, C.N.; Tran T.H. Study to evaluate the effects of climate change on rice yield in the Mekong Delta. Sci. Tech. Hydrometeorol. J. 2011, 611, $1-5$. 